\title{
Compórtate. La biología que hay detrás de nuestros mejores y peores comportamientos.
}

Sapolsky, R. 2018. Compórtate. La biología que hay detrás de nuestros mejores y peores comportamientos. Madrid: Capitán Swing Libros.

Comentario a cargo de: Dr. Leonardo González Galli. Investigador Adjunto del Consejo Nacional de Investigaciones Científicas y Técnicas (CONICET, Argentina).

Profesor Adjunto de Didáctica de la Biología, Profesorado de Biología, Facultad de Ciencias Exactas y Naturales, Universidad de Buenos Aires. leomgalli@gmail.com

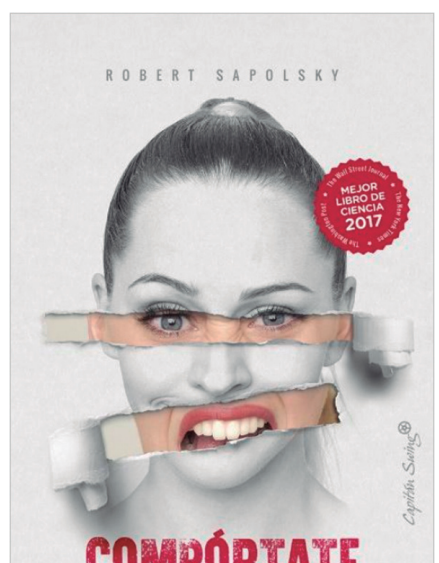

Es bien sabido que las interpretaciones biológicas de la mente y el comportamiento humano siempre han sido, y son, motivo de polémica. Las razones no son difíciles de comprender: las explicaciones biológicas han sido utilizadas repetidas veces en la historia para justificar sistemas sociales injustos (racistas, sexistas, etc.), cuando no genocidios. Ese es un hecho innegable que debemos tener siempre presente al tratar estos temas. Sin embargo, esa prevención ha llevado a muchos/as a una suerte de "negacionismo biológico", esto es, a la perspectiva según la cual lo que los humanos somos está totalmente dado por la cultura en la que crecemos. Como suele suceder con tantos temas polémicos, pasamos de un extremo al otro: del reduccionismo y determinismo biológicos (lo que se suele denominarse biologicismo) al reduccionismo y determinismo sociocultural (que, por analogía, llamaré socio-culturalismo). El socio-culturalismo tiene un fuerte peso en ciertos sectores políticos y académicos. El problema es que, aunque política e ideológicamente más simpático (bueno, esto, desde ya, depende de la ideología de cada quién), el socio-culturalismo es tan falaz como el biologicismo. Para decirlo de una vez: hace décadas que en la Biología está claro que ningún rasgo biológico está, ni puede estarlo, totalmente determinado por los genes ni por el ambiente. La vieja dicotomía naturaleza versus crianza está totalmente superada, y entender eso es condición necesaria para avanzar en la comprensión de nuestra mente y comportamiento. Así, el hecho de que muchas discusiones sigan planteándose en término de dicha dicotomía solo muestra lo propensos que somos los/as humanos/as (sí, incluidos/as intelectuales y académicos/as) a los planteamientos simplistas y maniqueos.

Esta introducción es necesaria para apreciar el valor de este extraordinario libro del antropólogo biológico, primatólogo, neuroendocrinólogo y gran divulgador científico estadounidense Robert Sapolsky. Y es que Compórtate es, sin dudas, la obra más completa, actualizada, y sofisticada, a la vez que accesible, sobre la biología de la mente y el comportamiento humanos. El libro es, eso sí, extenso: casi mil páginas. Pero es que el tema lo merece. En los diecisiete capítulos que componen el libro, Sapolsky recorre casi todos los grandes temas que nos preocupan, entre ellos el origen biológico de algunas diferencias comportamentales entre varones y mujeres y de algunas formas de agresión. El/ la lector/a podría pensar ahora "ipero si hay miles de libros que abordan esos temas!". Es cierto. Sin embargo, el libro de Sapolsky tiene varias virtudes que son escasas en el universo literario sobre estos temas.

La primera de dichas virtudes es que aborda estos temas desde las dos grandes perspectivas biológicas. Esto es, ofrece tanto interpretaciones desde las llamadas causas próximas (los factores fisicoquímicos que operan sobre el organismo individual) como desde las Ilamadas causas últimas (las razones histórico-evolutivas que explican por qué los organismos actuales somos cómo somos). Así, el autor analiza tanto las causas neuroendocrinológicas, genéticas y ambientales de nuestros comportamientos (causas próximas) como las interpretaciones evolucionistas (causas últimas) de dichos comportamientos. 
La segunda virtud, y aquí volvemos al tema del párrafo introductorio, es que Sapolsky se esfuerza (con éxito) en mostrarnos la complejidad de las interacciones entre los factores biológicos y los ambientales que determinan lo que somos. Es decir, el autor logra zafarse de la superada dicotomía a la que hacía referencia antes. Mencionaré solo un ejemplo. Con frecuencia se afirma que los altos niveles de testosterona son la causa de comportamientos agresivos. Dicho así, pareciera que, de un modo lineal, los altos niveles de testosterona causan la conducta violenta. Sin embargo, en el capítulo cuatro, Sapolsky explica, a partir de las más recientes y rigurosas investigaciones, que el efecto de la testosterona consiste, más bien, en aumentar las probabilidades de que hagamos lo que sea necesario para alcanzar y mantener un alto estatus social: si crecimos y vivimos en una sociedad en la que eso se logra mediante la competencia agresiva, entonces, los altos niveles de testosterona nos harán más proclives a comportamientos agresivos, pero si, en cambio, crecimos y vivimos en una sociedad en la que los individuos de más prestigio son los más cooperativos, entonces, los altos niveles de testosterona nos harán más proclives a comportamientos cooperativos. ¿Tiene entonces la agresividad un origen biológico o cultural? La pregunta está mal formulada: la dicotomía es falsa. Un detalle: al analizar los modos en que genes y entorno interactúan, Sapolsky explica algunos efectos epigenéticos (esto es, cambios en los patrones de expresión génica inducidos por factores ambientales) y ofrece una justa valoración de la investigación en este campo, algo que se agradece dada la explosión de mala literatura que tiene lugar desde hace algunos años en relación con este tema (esto suele suceder con todo tema que se pone de moda).

Una tercera virtud es que el autor ofrece, además de las explicaciones basadas en los modelos de la biología, agudas reflexiones sobre la naturaleza de los debates asociados a dichas explicaciones. En relación con esto último, Sapolsky expone con frecuencia cómo los factores ideológicos sesgan la investigación y el debate público en relación con estos temas. También explicita, en consonancia con la mejor epistemología actual, que todo modelo científico es necesariamente limitado en su alcance explicativo, y que esto impone la necesidad del pluralismo teórico.

A estas observaciones sobre el contenido del libro permítaseme agregar dos sobre la forma. Sapolsky escribe muy bien. Sabe ser ameno y claro sin traicionar las ideas que quiere comunicar, y sin caer en la superficialidad con pretensiones humorísticas que es tan frecuente en mucha literatura de divulgación actual. Para decirlo de otro modo, Sapolsky respeta el intelecto $\mathrm{del} / \mathrm{de}$ la lector/a, no lo subestima, por lo que el libro exige una lectura atenta y en cierta medida esforzada, pero amena. Por otro lado, la edición de la editorial Capitán Swing es, en relación con el diseño y la calidad, todo lo que un/a amante de los libros (en papel) puede desear, y la traducción (algo siempre problemático) es aceptable.

Por último, una breve reflexión didáctica. El libro de Sapolsky ofrece al/a la docente de biología un sinfín de ejemplos atractivos para llevar a las aulas análisis complejos que muestran cómo los factores biológicos y los socioculturales interactúan en la determinación de nuestra mente y comportamiento.

Solo una enseñanza de este tipo podrá ayudar a los/ as estudiantes a comprender qué aspectos de nuestro comportamiento y pensamiento se pueden explicar desde la biología y cuáles otros, en cambio, demandan otros enfoques teóricos, por ejemplo, los que ofrecen las ciencias sociales. Este es, tal vez, el modo más prometedor para ayudar a los/as estudiantes a lidiar con todas las perspectivas reduccionistas y deterministas que permean la cultura popular. Así, y volviendo a las reflexiones iniciales, necesitamos con urgencia análisis rigurosos que nos ayuden a abandonar las posturas extremas y contrapuestas, e ideológicamente lastradas en ambos extremos, que, con frecuencia, obturan las posibilidades de que el público general (pero también muchos/as académicos/as) avance en la comprensión de las causas de nuestros pensamientos y comportamientos. Bueno, el libro de Sapolsky es, sin dudas, un buen remedio para estos males. Y esto queda claro ya en las primeras páginas, desde las que el autor advierte que "(...) no se puede empezar a comprender algo como la agresividad, la competencia, la cooperación y la empatía sin la biología; digo esto por una cierta clase de científicos sociales que creen que la biología es irrelevante y algo sospechosa ideológicamente cuando se piensa en la conducta social humana" y que "(...) estará usted igual de equivocado si solo confía en la biología; esto lo digo por cierto tipo de fundamentalistas moleculares que creen que las ciencias sociales están destinadas a ser devoradas por la ciencia 'auténtica'" y, luego, que "(...) verá que, al hablar de los distintos aspectos de un comportamiento, no tiene sentido distinguir entre los que son 'biológicos' y aquellos que podrían ser descritos por ejemplo como 'psicológicos' o 'culturales'. Están totalmente entrelazados". Los diecisiete capítulos, las mil páginas, que siguen a esta advertencia inicial demuestran de un modo contundente su veracidad. 